УДК 338.242

\title{
ВИЗНАЧЕННЯ ОСНОВНИХ ВЛАСТИВОСТЕЙ СИСТЕМИ ЗАБЕЗПЕЧЕННЯ ЕКОНОМІЧНОЇ БЕЗПЕКИ ПІДПРИЕМСТВА
}

\author{
Павліченко В.М., к.ю.н., ст. викладач (ХІФ УДУФМТ)
}

В статті досліджено сутність $і$ властивості системи забезпечення економічної безпеки підприсмства як соияіально-економічної системи.

Визначено, щзо вона має наступні властивості: складна, велика, відкрита, нелінійна, динамічна, неоднорідна, багаторівнева, призначена для певної мети, змімана (за походженням $і$ за природою елементів), керована, за типом оператора системи -«біла шухляда», система 3 комбінованим управлінням, організаційна.

Ключові слова: економічна безпека підприємства, система забезиечення економічної безпеки підприсмства, властивості системи забезпечення економічної безпеки підирисмства

\section{ОПРЕДЕЛЕНИЕ ОСНОВНЫХ СВОЙСТВ СИСТЕМЫ ОБЕСПЕЧЕНИЯ ЭКОНОМИЧЕСКОЙ БЕЗОПАСНОСТИ ПРЕДПРИЯТИЯ}

\author{
Павличенко В.Н., к.ю.н., ст. преподаватель (ХИФ УГУФМТ)
}

В статье исследована сущность и свойства системы обеспечения экономической безопасности предприятия как сочиально-экономической системьл.

Определено, что она имеет следующие свойства: динамическая, неоднородная, многоуровневая, предназначенная для определенной цели, смешанная (по происхождению и по природе элементов), управляемая, по типу оператора системь - "бельй ящик", система с комбинированным управлением, организаиионная.

Ключевые слова: экономическая безопасность предприятия, система обеспечения экономической безопасности предприятия, свойства системы обеспечения экономической безопасности предприятия

\section{DETERMINATION OF BASIC PROPERTIES OF THE SYSTEM OF PROVIDING OF ECONOMIC SECURITY OF ENTERPRISE}

\author{
Pavlichenko V.N., PhD (legal sciences), senior teacher
}

(Kharkiv Institute of Finance Ukrainian State University of Finance and International Trade)

In the article the essence and properties of the system of providing of economic security of enterprise are investigational as a socio-economic system.

The system of providing of economic security of enterprise is totality of constituents: aim, task, principles of its construction and functioning, objects of safety, subjects of safety, mechanism of its providing.

It is certain that it has the next characteristics: difficult, large, open, nonlinear, dynamic, multilevel, heterogeneous, intended for a certain goal, with the mixed variables, a "white box" is an operator S systems known fully, guided, with the combined management and other.

For every separate enterprise system of providing of its economic security will be unique. But results of this research will create the basic for development of such system for the Ukrainian enterprises of different industries.

Keywords: economic security of enterprise, system of providing of economic security of enterprise, properties of the system of providing economic economic security of enterprise

Постановка проблеми. Проблема забезпечення економічної безпеки підприємств (ЕБП) існувала завжди, для будь-якого підприємства незалежно від форми власності, розміру, галузі, специфіки діяльності. Особливо актуалізується ця проблема в теперішній час в Україні - в умовах фінансово-економічної кризи, політичної нестабільності, зростання інфляції, зниження платоспроможного попиту, падіння ВВП. Тому необхідним є дослідження системи забезпечення економічної безпеки підприємства (СЗЕБП), іiі сутності, структури, властивостей. Звісно, для 
кожного окремого підприємства система забезпечення його економічної безпеки буде унікальною (залежно від спеціалізації та структури виробничої діяльності та промислового потенціалу, місця суб'єкта господарювання на ринку, кваліфікації та дисциплінованості кадрів тощо), але результати дослідження будуть слугувати базисом для розроблення СЗЕБП для українських підприємств різних галузей i основою для забезпечення економічної безпеки як на мікро-, так і на макрорівні.

Аналіз останніх досліджень і публікацій. Проблемам забезпечення економічної безпеки підприємства присвячена велика кількість наукових праць як вітчизняних, так і закордонних учених: О.В. Ареф'євої, В.А. Богомолова, В.Ф. Гапоненко,В.С. Гусева, В.М. Геєця, С.О. Груніна, В.Л. Диканя, В.І. Дуженкова, В.А. Дьоміна, М.О. Кизима, Т.С. Клебанової, Г.В.Козаченко, Б.І. Кузіна, І.Л. Назаренко (Плєтникової), Є.А. Олейникова, В. П. Пономарьова та інших [1 - 8 та ін.].

Питання створення системи забезпечення економічної безпеки підприємств висвітлені у працях українських учених, які надають різні ії визначення, виділяють ऑї елементи, формулюють принципи, розроблюють механізм іiі забезпечення тощо. Так, О.В. Руда [9] розробила організаційно-економічний механізм, спрямований на реалізацію комплексу заходів, налаштованих на протидію загрозам і на підвищення рівня економічної безпеки підприємств машинобудування; в дослідженні Н.С. Іванової [10] розглянуто теоретичні, методичні та практичні основи оцінки ефективності системи економічної безпеки агропромислових підприємств; у дисертації Коробчинського О. Л. [11] обгрунтовано шляхи та запропоновано методику вдосконалення системи економічної безпеки підприємства; у роботі $\mathrm{H}$. Матвійчук [12] визначено складові системи економічної безпеки підприємства, у статті B.I. Франчук [13] визначено сутність системи забезпечення економічної безпеки акціонерного товариства та побудовано іiі модель; у статті Н.В. Прус [14] побудовано структурну схему взаємодії системи економічної безпеки із зовнішнім та внутрішнім середовищами підприємства, систематизовано принципи функціонування системи економічної безпеки підприємства; О. С. Хринюк та H.P. Корчовна запропонували нескладну схему роботи системи забезпечення економічної безпеки підприємства [15]. Українські учені здебільшого не приділяють уваги визначенню властивостей системи забезпечення економічної безпеки підприємства. I лише Є.І. Овчаренко досліджує систему економічної безпеки підприємства базуючись на загальній теорії систем [16] як складну соціальну систему, визначаючи iï сутність та деякі властивості, але визначення цих властивостей замало для створення базису побудови СЗЕБП на українських підприємствах.
Виділення недосліджених аспектів проблеми. В літературі недостатньо розробленими залишаються питання визначення основних властивостей системи забезпечення економічної безпеки підприємства.

Тому метою статті є дослідження СЗЕБП на основі загальної теорії систем як складної соціальноекономічної системи та визначення іiі основних властивостей.

Основний матеріал статті. Побудування надійної й ефективної системи економічної безпеки підприємства можливе лише 3 застосуванням системного підходу до іiі організації, з визначенням категорійного апарату, методологічної бази.

Досі в сучасній науковій думці немає єдиного підходу і до визначення змісту системи економічної безпеки підприємства, відповідно існують i розбіжності у поглядах на іiі елементи (об'єкти, суб'єкти, механізм забезпечення i т.д.). Багато науковців ототожнюють систему економічної безпеки із комплексом заходів по ії забезпеченню, що $\epsilon$ спрощенням. На нашу думку, треба розрізняти систему економічної безпеки підприємства (сукупність складових: фінансової; технікотехнологічної; інтелектуальної і кадрової; екологічної; інформаційної; політико-правової; силової) та систему забезпечення економічної безпеки підприємства (сукупність складових: мета, завдання, принципи іiі побудови та функціонування, об’єкти безпеки, суб'єкти безпеки, механізм іiі забезпечення).

Узагальнення складу та взаємозв'язків компонентів економічної безпеки підприємства за допомогою системного підходу та використання категорії "система" розвинулося у самостійний науковий напрямок відносно недавно. Але доцільність системотворення у царині економічної безпеки підприємства на засадах системного підходу та пов'язаного 3 цим використання категорії "система", як слушно зауважує Є.I. Овчаренко, розглянуто у безпекології поверхово [16]. На думку абсолютної більшості дослідників у царині безпекології, система економічної безпеки $\epsilon$ соціальною системою.

На нашу думку, СЗЕБП, хоча і не повністю тотожна системі економічної безпеки, яку досліджує Є.І. Овчаренко (він вважає складовими цієї системи лише об'єкти та суб'єкти безпеки, а СЗЕБП $\epsilon$ ширшою і включає ще принципи забезпечення ЕБП, механізм іiї забезпечення, функції, мету та завдання [12]), також $\epsilon$ соціально-економічною системою. Тому у статті ми досліджуємо СЗЕБП як особливий різновид соціально-економічних систем.

[17]:

Усім системам властиві наступні властивості

1) цілісність;

2) відносна відособленість від зовнішнього середовища; 
3) наявність зв'язків 3 зовнішнім середовищем;

4) структурованість - наявність частин i зв'язків між ними;

5) цілеспрямованість - підпорядкування всієї організації системи визначеній меті.

Цільове призначення системи - це ії головна властивість. Цілі, які ставить перед собою людина, рідко досяжні тільки за рахунок іiі власних можливостей або зовнішніх засобів, що має вона у даний момент. Звідси виникає проблемна ситуація. Проблемність існуючого положення усвідомлюється в кілька стадій: від неясного відчуття, що щось не так, до усвідомлення потреби, а потім до виявлення проблеми i, нарешті, до формулювання мети. Система - це засіб для досягнення мети.

Окрім перерахованих вище основних властивостей, загальних для всіх систем, система СЗЕБП має специфічні властивості.

Кожна ознака системи визначає одну 3 iї властивостей, що описує іiі стан - безліч істотних властивостей, які має система в конкретний момент часу. Інакше, це упорядкована сукупність значень параметрів внутрішніх і зовнішніх, що визначають хід процесів, що відбуваються в системі. Стан системи разом з іiі входами й виходами є однією 3 основних характеристик динамічних систем.

Параметри системи задаються і можуть бути як якісними, так і кількісними в відповідних одиницях, що мають певну розмірність. Властивості об'єктів системи можуть змінюватися в процесі іiі функціонування.

Як відзначає Є.I. Овчаренко [16], «систему ЕБП треба розглядати як складну систему, для якої притаманні як елементи самоорганізації, так i елементи кібернетичного управління» (..), вона «має декілька властивостей, похідних від властивостей економічних систем:

- відкритість і нелінійність СЕБП. Економічна система будь-якого підприємства задовольняє вимозі, що пред'являється до відкритих систем, - у ній постійно циркулюють потоки грошей, ресурсів, інформації тощо. Нелінійність СЕБП полягає в тому, що іiі реакція на внутрішні чи зовнішні фактори впливу досить часто непропорційна силі прояву цих факторів. В цій системі можливі такі стани, поблизу яких система може суттєво змінити характер свого функціонування;

$$
\text { - нерівноважність }
$$

безпекозабезпечувальних процесів. Практика переконливо доводить, що теоретичні моделі рівноважних систем в кінцевому рахунку виявляються нежиттєздатними. Безпека, доведена до своєї межі, припиняє будь-який розвиток. Вона суперечить принципу мінливості;

- багатовекторність функціонування СЕБП. Як і в будь-якому нелінійному середовищі, на підприємстві можуть одночасно існувати багато шляхів розвитку процесів. 3 точки зору синергетики, як наукового підходу, що є логічним продовженням загальної теорії систем, майбугнє імовірнісне, неоднозначне, але, разом 3 тим, воно не може бути будь-яким. Аналіз безпекозабезпечувальних процесів переконливо показує, що лінійний характер розвитку i рівноважні стани зовсім не $є$ домінуючими в реальності, а непередбачуваність поведінки СЕБП є загальновідомою» [16].

Отже, СЗЕБП: складна; відкрита; нелінійна; ймовірнісна.

Але цим переліком не вичерпується опис властивостей СЗЕБП як системи. Тому скористаємося класифікацією систем, наявною в літературі, щоб визначити інші важливі для подальшого дослідження властивості СЗЕБП.

Системи класифікуються за багатьма ознаками.

$13 a$ походженням: штучні (створені людиною); природні (створені природою); змішані (створені людиною для певних цілей, але містять і природні елементи). СЗЕБП містить як елементи, створені людиною (машини, механізми, будівлі тощо), так і елементи природного походження (люди - кадри). Тому вона є змішаною.

2 За фактором часу: статичні - системи, у яких не відбувається зміна в часі; динамічні системи, у яких відбувається зміна в часі [17]. У СЗЕБП здійснюються значні зміни у часі (i y структурі управління, i у ефективності функціонування), тому вона є динамічною.

33 природою елементів: матеріальні (неорганічної природи - фізичні; хімічні; геологічні; живої природи - організми; популяції; екосистеми; соціальні); абстрактні (гіпотези; теорії; наукові знання; мовні системи; логічні системи). За цією класифікацією СЗЕБП є матеріальною системою, адже вона містить у собі як елементи живої природи (люди), так і неживої (деякі об’єкти безпеки створені людиною основні засоби, матеріальні цінності та ін.), і СЗЕБП є нематеріальною системою, адже вона містить сукупність принципів забезпечення безпеки, а це - абстрактна система, яку можна віднести до логічних систем. Тому виникає необхідність доповнити існуючу класифікацію третім підвидом систем: змішані (за природою елементів).

43 а кількістю рівнів: однорівневі; багаторівневі (багатошарові, полістратні), у тому числі ієрархічно організовані. СЗЕБП має декілька рівнів управління, а за структурою - складається 3 декількох підсистем, а ті, в свою чергу - 3 елементів. Тому СЗЕБП можна вважати багаторівневою системою.

53 а характером иілей: призначені для певної цілі; здатні обирати ціль і до неї прагнути. СЗЕБП не може змінити мету свого існування забезпечення прийнятного рівня економічної безпеки 
підприємтва Тому вона є призначеною для певної (вищеназваної) мети.

6 Залежно від того, чи мають $\ddot{x}$ компоненти - об'єкти, агенти, продукти та ін. ідентічні характеристики або різні: однорідні; неоднорідні [18]. Елементи, які входять до складу СЗЕБП, різні за природою та властивостями. Наприклад, елемент «принципи забезпечення безпеки», елемент «об'єкт безпеки» тощо. Тому СЗЕБП $є$ неоднорідною системою.

$73 a$ керованістю: керовані (якщо існують можливості змінити характеристики системи або іiї окремих частин - підсистем, об'єктів, елементів - за рахунок штучно створюваних зовнішніх впливів) ; некеровані, в тому числі самоврядні i ті, що самоорганізуються (в протилежному випадку). СЗЕБП піддається цілеспрямованому впливу керуючих органів. На неї доцільно впливати 3 метою приведення іiі до бажаного стану (ефективного функціонування), тому вона є керованою.

У загальному схематичному виді управління системою представлено наступним чином (див. [17, c. 104]). Виділено окремо систему $\mathrm{S}$, що підлягає управлінню $\mathrm{V}$, i керуючу систему Sy, що це управління виробляє. Для вироблення управління потрібне передбачення його наслідків, тобто потрібна модель усієї ситуації. За допомогою цієї моделі визначається, яке управління подати на вхід у систему, тому схема зображена усередині керуючого блоку. I методи вироблення управління, і способи його здійснення, i сам результат керування в чималому ступені визначається тим, що відомо про систему і що враховується при виробленні керування, тобто тим, яка модель керованої системи і наскільки вона відповідає реальній системі.

Враховуючи різні аспекти відповідності моделі керування реальними системами, вченими розроблено наступну класифікацію систем [17].

83 за описом вхідних (x), вихідних (y) $i$ внутрішніх перемінних (z) системи поділяються на: системи 3 кількісними перемінними (дискретними; безперервними; системи з змішаними перемінними; системи 3 якісними перемінними (зі змістовним описом; 3 формалізованим описом; зі змішаним описом); системи зі змішаними перемінними. Вхідні (x), вихідні (у) та внутрішні перемінні (z) СЗЕБП описуються як якісним, так і кількісним способом (наприклад, чисельність працівників, вартість основних фондів тощо - змінні з кількісним описом; компетенції працівників - змінні з якісним описом і т.д.). Тому СЗЕБП можна вважати системою зі змішаними перемінними.

93 З типом опису оператора (S) системи бувають: чорна шухляда - $\mathrm{S}$ невідомо; непараметризований клас - $\mathrm{S}$ відомо частково; параметризований клас - S відомо до параметрів; біла шухляда - S відомо цілком. Оператор S системи СЗЕБП відомий для керівництва системи повністю, тобто, наявна уся інформація при внутрішнє середовище цієї системи, адже вона створена людиною для досягнення вище названої мети. Тому за типом оператора системи вона $\epsilon$ «білою шухлядою».

103 а способом керування: керовані ззовні (без зворотнього зв"язку, регулювання, керування за параметрами, керування за структурою); самокеровані (програмне керування, автоматичне керування, параметрична адаптація, само адаптація (структурна організація); 3 комбінованим управлінням (автоматичні, напівавтоматичні, автоматизовані, організаційні) [17; 19, с. 38-39]. СЗЕБП, по-перше, $є$ підсистемою системи вищого рівня (підприємства), а по-друге, $є$ відносно самостійною. Тому вона є системою з комбінованим управлінням, а саме - організаційною.

Використовується, звичайно, і ряд інших класифікацій, наприклад виділяють прості, складні і дуже складні, а також великі системи (залежно від числа i характеру взаємозв'язків між елементами i зовнішнім середовищем), реальні й уявні (віртуальні) системи, цілеорієнтовані (цілеспрямовані) i ціннісноорієнтовані (якщо відсутні чіткі цілі i їх ієрархія) і так далі. Природно, можна класифікувати системи і за будь-якою іншою корисною ознакою, а також розгортати їх в ієрархічні структури.

Визначені нами властивості системи СЗЕБП зображені на рисунку 1 .

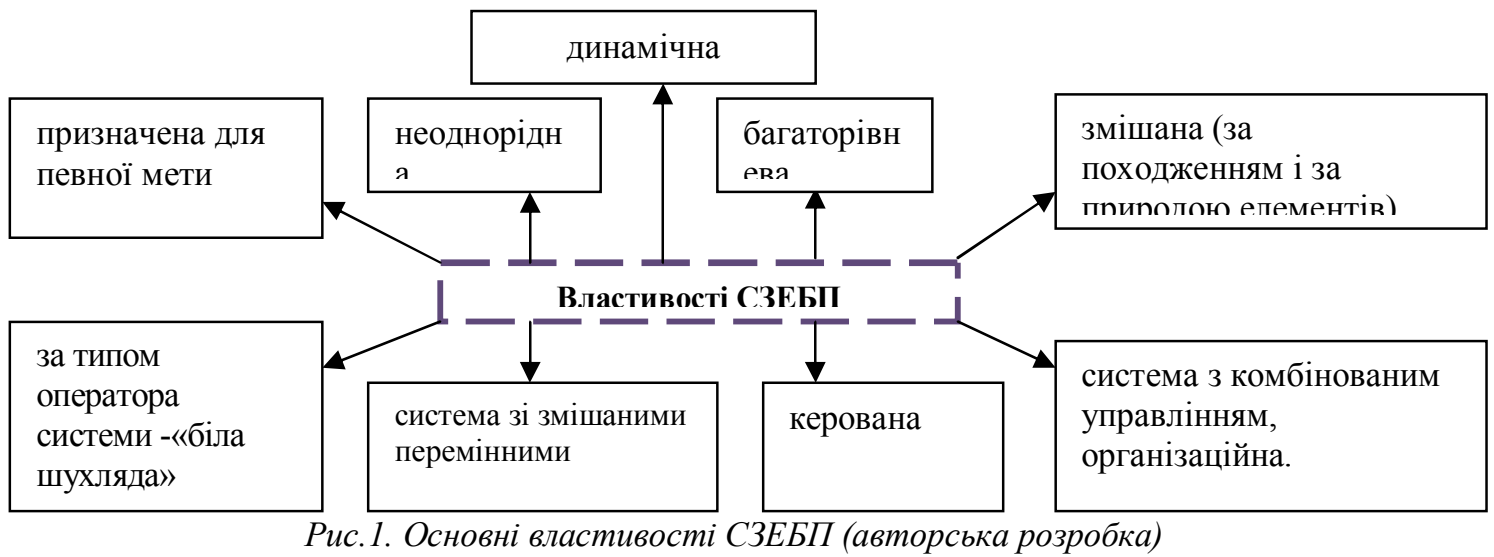

Вісник економіки транспорту і промисловості № 49, 2015 
Висновки i перспективи подалыших досліджень В статті досліджено сутність системи забезпечення економічної безпеки підприємства та іiі властивості як соціально-економічної системи. Нами визначено, що окрім існуючих в літературі властивостей (складна; відкрита; нелінійна; ймовірнісна), вона має наступні властивості: динамічна, неоднорідна, багаторівнева, призначена для певної мети, змішана (за походженням i за природою елементів), керована, за типом оператора системи -«біла шухляда», система 3 комбінованим управлінням, організаційна.

Напрямками подальших досліджень може бути уточнення елементів СЗЕБП, зокрема принципів iii формування та функціонування, а також розроблення алгоритму побудування такої системи для підприємств різних галузей з урахуванням їхньої специфіки.

\section{СПИСОК ЛІТЕРАТУРИ}

1 Основы экономической безопасности (государство, регион, предприятие, личность) [Текст]: Учебно - практ. пособие. / В.И. Видяпин, В.И. Дуженков, Д.И. Ефимов и др./Под. ред. Е.А. Олейникова - М.: ЗАО "Бизнес-школа Интел СИНТЕЗ", 1997. - 279 с.

2 Гапоненко В.Ф. Экономическая безопасность предприятий. Подходы и принципы [Текст]. / В.Ф. Гапоненко, А.Л. Беспалько, А.С. Власков - М.: Издательство «Ось-89», 2007. - 208 с.

3 Экономика и организация безопасности хозяйствующих субъектов [Текст]: учеб. для вузов / В.С. Гусев, В.А. Демин, Б.И. Кузин и др. - 2-е изд. СПб.: Питер, 2004. - 281 с. - (Серия «Учебник для вузов»).

4 Дикань В.Л. Комплексна методика визначення рівня економічної безпеки, оцінки ризиків та ймовірності банкрутства підприємства [Текст]: монографія / В.Л. Дикань, І.Л. Назаренко Харків:УкрДАЗТ, 2010. - 142 с.

5 Дикань В.Л. Економічна безпека підприємства [Текст]: навч. посібник. / В.Л. Дикань, I.В. Воловельська, О.В. Маковоз. - Харків: УкрДАЗТ, 2011.-266 c.

6 Ареф'єва О.В. Планування економічної безпеки підприємств [Текст] / О.В. Ареф'єва, Т. Б. Кузенко. - К.: Вид-во Європ. Ун-ту, 2005. - 170 с.

7 Моделювання економічної безпеки: держава, регіон, підприємство [Текст]: Монографія. / В.М. Геєць, М.О. Кизим, Т.С. Клебанова, О.І. Черняк та ін. - Харків.: ВД “ІНЖЕК”, 2006. - 240 с.

8 Козаченко Г. В. Економічна безпека підприємства: сутність та механізм забезпечення [Текст]: монографія / Козаченко Г. В., Пономарьов В. П., Ляшенко О. М. - К. : Лібра, 2003. - 280 с.
9 Руда О.В. Формування системи економічної безпеки підприємств машинобудування [Текст]: автореф. дис ... канд. екон. наук / О. В. Руда . - Тернопіль, 2013 . - 20 с.

10 Іванова Н.С. Оцінка ефективності системи економічної безпеки агропромислових підприємств [Текст]: автореф. дис ... канд. екон. наук / Н. С. Іванова . - Дніпропетровськ, 2011 . - 20 с.

11 Коробчинський О.Л. Організація та функціонування системи економічної безпеки підприємств будівельного холдингу [Текст]: автореферат дис. ... канд. екон. наук / О. Л. Коробчинський. - К., 2010. - 20 с.

12 Матвійчук Н. М. Теоретичні основи формування системи економічної безпеки підприємства [Текст] / Н. М. Матвійчук // Формування ринкової економіки в Україні: [зб. наук. праць]. - Львів, 2014. - Вип. 31 - С. 37-44.

13 Франчук B.I. Теоретична модель системи забезпечення економічної безпеки акціонерних підприємств [Текст] / B.I. Франчук// Науковий вісник НЛТУ України. - 2010. - Вип. 20.8. - C. 155-162.

14 Прус Н.В. Система економічної безпеки підприємства: поняття, сутність, принципи [Електронний ресурс]/ Н.В. Прус . - Режим доступу: http://www.global-national.in.ua/vipusk-1-2014/180prus-n-v-sistema-ekonomichnoji-bezpeki-pidpriemstvaponyattya-sutnist-printsipi.

15 Хринюк О. С., Корчовна Н.Р. Система забезпечення економічної безпеки підприємства: основні елементи [Електронний ресурс] / О.С. Хринюк, Н.Р. Корчовна // Електронне наукове фахове видання "Ефективна економіка". - Режим доступу: com.ua/?op=1\&z=3927

16 Овчаренко Є.I. Система економічної безпеки підприємства: ознаки та принципи функціонування [Електронний ресурс] / Є.I. Овчаренко. http://vuzlib.com.ua/articles/book/35302-

Sistema_ekonom $\% \mathrm{D} 1 \% 96 \mathrm{chno} \% \mathrm{D} 1 \% 97$ bezpeki/1.htm

17 Перегудов Ф.И. Введение в системный анализ [Текст]: учеб. пособие для вузов / Ф.И. Перегудов, Ф.П. Тарасенко. — М.: Высш. шк.,1989. -367 c.

18 Лившиц В.Н. Основы системного мышления и системного анализа [Текст] / В.Н. Лившиц. - М.: Институт экономики РАН, 2013. - 54 c.

19 Сорока К.О. Основи теорії систем i системного аналізу [Текст]: навч. посібник / К.О. Сорока. - 2-ге вид., перероб. і доп. - Х.: Тимченко, 2005. $-288 \mathrm{c}$.

Рецензент д.е.н., професор УкрДУЗТ Кірдіна О.Г. Експерт редакційної колегії к.е.н., доцент УкрДУЗТ Назаренко І.Л. 